\title{
Sciendo
}

DOI: $10.2478 /$ rjp-2020-0022

Rom J Psychoanal 2020, 13(2):175-184

Rom J Psychoanal

\section{DISCUSSION ON “SOME NOTES ON FUSION” \\ BY PAOLO FONDA $A^{26}$}

Brînduşa Orăşanu ${ }^{27}$

Abstract: In his conference, Paolo Fonda highlights the concepts of "microarea of fusion" and of "separation coefficient", which makes it possible to think in terms of quantitative factors. The perspective of the gradualness of some mechanisms or phenomena implies the existence of a theoretical continuum between psychotic and neurotic functioning. Another aspect addressed concern symbolic component versus concrete elements of the communication, and ambiguity as a way of moderating reality. Authors of prose and poetry are brought to support this psychoanalytic thinking.

Keywords: micro-area of fusion, separation coefficient, quantitative factor, theoretical continuum, ambiguity.

\section{Introduction}

I'd like to thank Paolo Fonda for this reflection on fusion, a reflection that reminds us that no step towards knowing the human psyche is definitive, that psychoanalytic theories not only originate in

\footnotetext{
${ }^{26}$ Fonda, P., Some notes on fusion, in Conference "The Archaic" organised by The Romanian Society of Psychoanalysis, Bucharest, 2-4 nov. 2018; published in RJP 2/2019, p. $37-55$ and RJP 1/2020, p 29-44.

${ }^{27}$ Romanian Society of Psychoanalysis; obrindusa@yahoo.com
} 
clinical practice, but also that, once formulated, they return to the clinical context in order to be detailed, relativized and hence, enriched.

I will start with the metaphor in the Conclusions chapter, that we stay in the water at least until our knees for all our lives, and that this constitutionally amphibious being is rather a quality that allows us not only to survive but also to live life to the fullest (Fonda). This is a powerful metaphor that you tend to develop and, at the same time, you wouldn't want to develop it excessively; I will come back to it because its destiny is probably to be easily remembered.

\section{On the quantitative factor within a theoretical continuum}

When we refer to fusion, we usually think of a complete fusion, like desire or fear (separation or fusion anxiety), that our patients are struggling with, especially in their borderline states. The exceptional idea of partial fusion changes this perspective and also makes it more complex. It may also call upon a differentiation from the concept of hysterical identification, also partial; apart from the difference between primary versus secondary register, the passive (fusion) versus active (hysterical identification) character of the subject may be added to this differentiation: actively, he initiates identification, he identifies himself with ..., while in a, let's say, proto-identification, the subject lets himself be identified with ... When projective identification operates, the subject is once again active: he identifies the object with ... Or, for example, what happens when contemplating a work of art, or while reading a literary text? Does the reader experience a hysterical identification, sought from the beginning, or does the reader allow himself passivelyreceptive, according to the Bionian model of reverie, to be affected by 
the content of the work through a kind of projective identification at "spatial and temporal distance"?

Paolo Fonda highlights the relationship between the concept of projective identification - communicative or evacuative or aiming to control the object - and the concept of "micro-area of fusion", a preexisting area or one to be enlarged, that allows for projective and introjective exchanges with the external object. The importance of these exchanges was highlighted by Melanie Klein, as well as the importance of the relation between introjection and projection, a relation that some authors place among the criteria of assessing a psychoanalytic cure.

Also, the fusion areas, different in size, may coexist with the boundaries of the Self, which also have different permeability zones, more or less (pre)disposed to transform into a fusion zone. We could three-dimensionally represent this image, on the one hand with vertical changes in the size and resistance of the Self's boundaries, on the other hand with changes in the horizontal dimension of the boundary, which is neither uniform, nor static, allowing Paolo Fonda to use the concept of separation coefficient. This image suggests that the boundaries of the Self are alive, that there is a kind of pulsation of the fusion and separation phenomena, which somehow resembles the image proposed by Florence Guignard's (1997) expression ‘psychic breath' which she used in relation to the phenomenon of projective identification.

The idea of a coefficient applied to the terms of separation and fusion continues the Freudian perspective of the quantitative factor, starting with Freud's assertion that between normality and pathology there is only a difference of degree (including paranoid projection), an idea confirmed by Bion along with the extension of the concept of projective identification in such a way that the mechanism becomes pathological only along with the "massive" character. 
The perspective of the gradualness of some mechanisms or phenomena implies the existence of a theoretical continuum, a continuum considered by Melanie Klein to be amidst psychotic and neurotic functioning, by Harold Searles relative to borderline functioning as being more or less part of the human condition, by Otto Kernberg in relation to the narcissistic elements of personality, or by Michel de M'Uzan in relation to identity but also to the metaphorization capacity.

The idea of continuum is useful in psychoanalytic theory because, on the one hand, it allows the clinician to think in terms of regression and resumption of psychic development in the deficient points, and on the other hand, it allows the enrichment of the psychoanalytic thinking with more subtle differentiations. These differentiations in theory also return to clinic and improve it because every analysand, being a unique individual - substantially and also as subjective experience of self - will be better understood and helped by an analyst with a capacity to relativize what he/she already knows, or to think dialectically (dialectic mentioned for that matter by Paolo Fonda at the beginning of the presentation).

\section{Symbolic versus concrete}

Another aspect addressed by Paolo Fonda concerns symbolic communication, namely: symbolic thinking requires a sense ofseparateness and is affected by fusion, but symbols require, in communication, a concrete component to accompany them in order to be entirely communicated, and this component mainly passes through fusion channels (Fonda). 
Here, I would like to make two remarks regarding the concrete character. The first concerns a connection that we can make between thinking, communicating it and the dream-work, taking into account one of Freud's observations from the Interpretation of Dreams regarding figurability: "...once the dream-thought has been transformed into pictorial language, contrasts and identifications of the kind which the dream-work requires, and which it creates if they are no already present, can be established more easily than before between the new form of expression and the remainder of the material underlying the dream. This is so because in every language concrete terms, in consequence of the history of their development, are richer in associations than conceptual ones" (Freud, 1900, p. 340). It is about figurability as a factor of transforming latent dream-thoughts into its manifest content. Melanie Klein also refers to the concrete way in which the world of internal objects is experienced at the level of deep unconscious phantasies (Klein, 1940, pp. 125-153), because each internal object is not only invested with emotional qualities, but also with sensory qualities from the experiences of pleasure or pain that the child experienced in the relationship with his/her parents. As Didier Houzel notes, if Freud follows the oneiric journey from abstract to concrete, Klein follows the path of psychic development from the sensitive experience towards the capacity to express through symbols and words. Paolo Fonda, through his assertion, takes this reflection further, finding a common denominator of communication with oneself and the other, which requires a dose of concreteness, even if we are dealing with communication through symbols.

Freud stated: "[...] so that, to our surprise, we find the child and the child's impulses still living on in the dream." (1900, chapter V, p. 191). We can say: the child with no words, the infans, subsists in the 
child with words, who can already use verbal language. Fonda elaborates on the issue: in other words, the most sophisticated adult is accompanied in thinking and communication by the infans not only because he/she lives on, but because the first one cannot go without the second one - as I understand Fonda's statement - in the very process of using symbols; more precisely, the infans subsists not only in the dream and not only with his/her impulses, but also in the symbolic vigilant thought, and with his/her sensory character.

My second remark regarding the concrete character suggests a reference from literature this time. Commenting on the text of one of his fellows about a metaphor used by Paul Valéry, Jorge Luis Borges (who transformed literary criticism into a creation in its own right) stated that symbols don't mean changing a figure with an abstract name, but propose a double intuition: "The hungry and lean she-wolf in the first canto of the Divine Comedy is not avarice: it is a she-wolf and it is also avarice, like in dreams" (Borges, 1937, p. 434, my emphasis). And further on, also regarding metaphor: "The metaphor is the momentary contact between two images, not the methodical assimilation of two things" (p. 435). With these comments, Borges arrives at the issue of concrete-sensory dose in the metaphor and, at the same time, at the issue of ambiguity, also necessary in metaphorical language.

\section{On ambiguity}

Following Winnicott, among others, with his concept of environmentmother and Bleger with his term meta-ego, Paolo Fonda emphasizes the importance of primarily fusional space with its "ambiguity," which can be seen as a defense mechanism that protects the ego from the direct impact of reality, a reality which contains, 
among others, the element of linear irreversible time. I would add that ambiguity - theoretically used by Freud with regard to the concept of ego as instance and person - can be seen as a variant of retrieving transitionality in a Winnicottian sense, without losing the already conquered capacity of separation and differentiation, and which implies the possibility of an oscillation between ambiguous and distinct; while confusion can be seen as a regression to a lack of differentiation that doesn't allow internal-external oscillation (or internal-external coexistence, depending on how we imagine things, in time or in space).

Paolo Fonda proposes ambiguity as a way of moderating reality, taming it.

This meta-ego, with its - should we look at them together? concreteness and ambiguity between fused and differentiated, was described by Walt Withman, again a reference to literary language, in one of his poems in the volume Leaves of grass, a poem Borges claims to show the reader's "momentary identification" with the protagonist of a work. Allow me to render it, because I have always considered that psychoanalysis can find a good support in literature, and can use it in order to confirm or illustrate thinking, to give some sort of tertiary body to its theories, in addition to its clinical body:

"These are really thoughts of all men in all ages and lands, they are not original wit me, /

If they are not yours as much as mine they are nothing, or next to nothing, / If they are not the riddle and the untying of the riddle they are nothing, / If they are not just as close as they are distant they are nothing. / This is the grass that grows wherever the land is and the water is, / This the common air that bathes the globe." (Whitman, Song of Myself, 17, 1892, pp. 66-67) 
In my opinion, this poem supports and continues the metaphor proposed by Paolo Fonda, which I resume, that we stay in the water at least until our knees for all our lives, and that this constitutionally amphibious being rather a quality that allows us not only to survive but also to live life to the fullest (Fonda). Finally, I bring up one last writer to advance in this metaphor (already collective!), this time on the vertical dimension, the temporal one, or that of depth of the "planetary" ${ }^{28}$ psychic ocean. I'm referring to Marcel Proust, who uses the body metaphor to express history. In In search of lost time, Time regained (1927), he concludes his book describing people as beings restricted in space but prolonged in Time:

"...I would therein describe men, if need be, as monsters occupying a place in Time infinitely more important than the restricted one reserved for them in space, a place, on the contrary, prolonged immeasurably since, simultaneously touching widely separated yearsand the distant periods they have lived through — between which so many days have ranged themselves - they stand like giants immersed in Time." (Proust, 1927, p. 368; my italics) "Prolonged immeasurably" can also mean above and beyond the life of an individual, i.e., filiation and parenthood. Proust has also intuited that sublimation is a solution based on the essential ambiguity between the individual and humanity, a solution to taming the solitude and the finitude of the human being.

Didn't Freud state that the individual leads a dual existence, one for himself (ego drives) and one for the species (sexual drives) (1914, p. 38)? I have the impression that Paolo Fonda and the other authors to whom I've referred, bring about, through their theory and poetry, a taming of this terrible scientific truth.

${ }^{28}$ John Kafka emphasizes the importance of the temporal function in the psychic equation (1989). 


\section{REFERENCES}

BION, W.R. (1959). Attaques contre la liaison. In: Réflexion faite. [Attacks on linking] Paris, PUF, 1983, pp. 105-124.

BION, W. R. (1962). Aux sources de l'expérience. [Learning from experience]. PUF, Paris, 2001.

BORGES, J. L. (1937). Liam O’Flaherty. In: Texte captive, [Captive texts]. Polirom, Bucharest, pp. 433-436, 2010.

BORGES, J. L. (1975). Walt Withman: Fire de iarbă. In Texte captive.

[Walt Withman: Leaves of Grass. In Captive texts]. Polirom, Bucharest, pp 198-202, 2010.

FONDA, P. (2018), Some notes on fusion, Conference "The Archaic" organized by the Romanian Society of Psychoanalysis, Bucharest, 2-4 Nov. 2018.

FREUD, S. (1900). Interpretarea viselor. Bucharest, Publishing House Trei, 2003. [The Interpretation of Dreams. In $S E$, vol. IV].

FREUD, S. (1914). Pentru a introduce narcisismul. In Opere (vol. 3), 57-102. Bucharest, Publishing House Trei, 2000. Rom. Transl. Gilbert Lepădatu. [On Narcissism: An Introduction. In SE, vol. XIV]

GUIGNRAD, F. (1997). Epître à l'objet. PUF, Paris.

HOUZEL, D. (1985). L'évolution du concept d'espace psychique dans l'oeuvre de Mélanie Klein et de ses successeurs. In Mélanie Klein aujourd'hui, Césura Edition, Lyon, pp 123-138, 1985.

KAFKA, J. (1989). Realităţi multiple în psihanaliză. [Multiple Realities in Clinical Practice] Bucharest, Publishing House Trei, 1999.

KLEIN, M. (1940). Morning and its relation to manic-depressive states. Int J Psychoanal., 21:125-153. 
PROUST, M. (1927). În căutarea timpului pierdut. Timpul regăsit. [Remembrance of Things Past. Time Regained]. Leda, Bucharest, 2008.

WITHMAN, W. (1892). Fire de iarbă. Cântec pentru mine însumi. 17. [Leaves of Grass, Book III, Song of Myself, 17] In Opere alese. Bucharest, Univers, 1992. Quoted by Borges, J. L., in op. cit., p. 201. 